\title{
PRELIMINARY RESULTS ON THE EFFECT OF 1-METHYLCYCLOPROPENE ON QUALITY OF PLUMS GROWN IN LATVIA
}

\author{
Vitālijs Radenkovs\#, Edìte Kaufmane, Edgars Rubauskis, and Dalija Segliṇa \\ Institute of Horticulture, Latvia University of Agriculture (formerly, Latvia State Institute of Fruit-Growing), \\ Graudu iela 1, Dobele LV-3701, LATVIA \\ \# Corresponding author, vitalijs.radenkovs@Ivai.lv \\ Contributed by Dalija Seglina
}

\begin{abstract}
Plums are one of the most popular, perspective and frequently consumed fruits in Latvia. Plums are typical climacteric fruits, respiration occurs during ripening. Respiration rate is mainly associated with synthesis of autocatalytic ethylene and depends of the cultivar of fruits. Metabolic processes occurring during plum storage cause changes in fruit quality. The aim of this work was to determine the effect of treatment by 1-methylcyclopropene (1-MCP) on physical and chemical characteristics and sensory qualities of five plum (Prunus domestica L.) cultivar fruits ('Adele', 'Sonora', 'Victoria', 'Stanley', 'Minjona') during four weeks of storage in a cool store-room at temperature $3 \pm 1^{\circ} \mathrm{C}$. The following analyses were performed to evaluate quality changes during storage: mass loss, concentration of total acids and soluble solids, firmness, and sensory qualities (colour, flavour, acidity, sweetness, firmness, and stone adherence). The study showed that treatment with 1-MCP had positive effect on fruit firmness during four weeks of plum storage, and there were significant differences in the content of total acids and soluble solids between 1-MCPtreated and control plum fruits. The results indicated that there were no significant differences in flavour (aroma) and colour between treated and untreated plum fruits, while 1-MCP-treated fruits were firmer and more sour.
\end{abstract}

Key words: 1-MCP, storage, physical-chemical indices, sensory evaluation, plum fruits.

\section{INTRODUCTION}

Plums are a highly perishable fruit and become overripe very fast (Khan and Sing, 2009). Storage and shelf-life is limited even at low storage temperature. Commercial storage and transportation conditions $\left(0-5{ }^{\circ} \mathrm{C}\right.$ and $80-95 \%$ relative humidity) partly delay the softening process, reduce mass losses and disease incidence, but there is high susceptibility to physiological disorders at low temperature such as chilling injury symptoms (Palau et al., 2003; Crisosto et al., 2009).

Ripening of climacteric fruits is regulated by ethylene, which initiates the biochemical and physiological changes related to fruit ripening and senescence (ageing), such as sugar and organic acid metabolism, fruit softening and skin colour (Khan and Sing, 2009). The shelf-life of plums determines their quality and acceptability by the consumers on the market. Consumers associate the fruit quality with their firmness, juiciness, and sweetness. Too soft fruits are characterised as a commodity with low quality and that have been stored too long (Galmarini et al., 2013).

Ethylene $\left(\mathrm{C}_{2} \mathrm{H}_{4}\right)$ is one of the simplest organic compounds with biological activity. Ethylene is gaseous substance that is physiologically active at a very low concentration -20 to $100 \mathrm{nl} \mathrm{L}^{-1}$ and can initiate ripening and accelerate ageing of plant organs (McKeon et al. 1995). All plant tissues synthesise ethylene, which is released in the environment. Its synthesis rate varies widely and depends mainly on the physiological condition of plant tissues and effect of environmental factors. Ethylene production by fruits and vegetables is generally promoted by physical injury, fungal infection, water stress, and elevated temperature up to $30{ }^{\circ} \mathrm{C}$ (Kader, 1987). Highest synthesis rate of ethylene occurs during fruit ripening, in the overripe stage, after tissue injury and when the fruit is stressed (Ievins, 2012).

At a certain phase of ripening, ethylene binds with appropriate receptors in fruit cells, which promotes completion of fruit ripening and beginning of cell degradation (Burg and Burg, 1967; Sisler and Lallu, 1994).

Several manufactured substances, which can compete with the ethylene binding, have been found to lead to a reduction of ethylene effects (Juhnevica et al., 2013). In 1989 and 1993, scientists from North Carolina State University, Blankenship and Sisler, observed that the artificial substance 2.5-norbornodiene (NDB) and diazocyclopentadiene 
(DACP) delayed softening and ripening in apples. However, none of these compounds are commercially acceptable due to high toxicity and manufacturing concerns (Fan et al., 1999).

Usually, the commercial strategies focus directly on the inhibition of ethylene perception or ethylene synthesis during the harvesting, storage, transportation, and processing (Watkins et al., 2002). One of the newest methods for controlling ethylene synthesis and hence decreasing ripening and ageing processes in climacteric fruits is 1-Methylcyclopropene (SmartFresh ${ }^{\mathrm{TM}}$ ) application, which has been broadly documented as an ethylene inhibitor (Abdi et al., 1998; Martinez-Romero et al., 2003; Candan et al., 2006; Watkins, 2006).

Metabolic processes in plum fruits are regulated predominantly by endogenous ethylene biosynthesis (Bapat et al., 2010; Alexander, Grierson, 2002). The inhibition of autocatalytic ethylene biosynthesis by 1-MCP has been attributed to reduction in the activities of 1-aminocyclopropane1-carboxylic acid synthase (ACS, EC 4.4.1.14) and 1-aminocyclopropane-1-carboxylic acid oxidase (ACO, EC 4.4.17.4) and their respective genes (Mathooko et al., 2001). 1-MCP can induce beneficial effects, such as delay of physicochemical changes related to the ripening process, as well as a reduction of decay, mass losses, and chilling injury (Blankenship and Dole, 2003).

Delay of ethylene production is one of options for prolonging the shelf-life of plum fruits.

The aim of this work was to study the effect of treatment by 1-methylcyclopropene (1-MCP) on physical and chemical characteristics and sensory qualities of five plum cultivar (Prunus domestica L.) 'Adele', 'Sonora', 'Victoria', 'Stanley', and 'Minjona' fruits during four weeks of storage.

\section{MATERIALS AND METHODS}

Materials and storage conditions. The research was carried out at the Institute of Horticulture, Latvia University of Agriculture in Dobele. Five plum cultivars ('Minjona', 'Sonora', 'Stanley', 'Victoria', 'Adele') fruits were harvested in August 2014 (in optimal maturity stage for each cultivar). Fruit average mass was recorded for each plum cultivar: 'Sonora' $-0.553 \pm 0.01 \mathrm{~kg}$; 'Adele' $-0.410 \pm$ $0.01 \mathrm{~kg}$; 'Victoria' $-0.402 \pm 0.01 \mathrm{~kg}$; 'Minjona' -0.314 $\pm 0.01 \mathrm{~kg} ;$ 'Stanley' $-0.272 \pm 0.01 \mathrm{~kg}$. For the storage, 7 $\mathrm{kg}$ plum fruits of each cultivar were collected and divided into two parts: fresh untreated (control C) and fresh plums treated with 1 -MCP at the concentration of $0.520 \mu \mathrm{L}^{-1}$ 1-methylcyclopropene. The 1-methylcyclopropene used was commercially obtained from Rohm and Haas Company "RandH" (Italy). Immediately after harvesting of plums, treatment with $1-\mathrm{MCP}$ was carried out at $18{ }^{\circ} \mathrm{C}$ in a hermetically closed fruit processing container for $12 \mathrm{~h}$.

The control and samples treated by $1-\mathrm{MCP}$ were stored four weeks in a cool store-room at temperature $3 \pm 1{ }^{\circ} \mathrm{C}$. Fruit quality was assessed before storage and after one, two, three, and four weeks of storage. After every storage period (a week), equal amounts (one-fourth of the initial plum sample) were removed, weighed, delivered to the laboratory, stored four hours at temperature $20{ }^{\circ} \mathrm{C}$ and $\mathrm{RH} 90 \%$, and then physicochemical indicators were evaluated and sensory analyses performed.

Physicochemical analyses. Firmness was estimated using a digital penetrometer (model TR 53205, Italy) equipped with a 8-mm diameter probe; peak destructive force was expressed in newtons $(\mathrm{N})$. Flesh firmness, was measured on two opposite sides of each plum fruit. Mass losses were determined as described previously (Bliek et al., 1995).

Titratable acidity was determined using standard method LVS EN 12147:2001 and quantified by titration of $1 \mathrm{ml}$ of juice (automatic titration DL 21, Mettler Toledo, Swiss) with $0.1 \mathrm{M} \mathrm{NaOH}$ to a $\mathrm{pH} 8.1$; expended amount of $\mathrm{NaOH}$ was expressed as percentage of malic acid.

Soluble solid content was determined using standard method LVS EN 12143:2001. Ten fruits of each cultivar were selected and processed with a hand blender Bamix ${ }^{\circledR}$ of Switzerland, model SwissLine (Liechtensteinn, Switzerland) into puree for which the content of soluble solids (in ${ }^{\circ}$ Brix) was determined using a digital electronic refractometer (type Pal-1, Tokio, Japan).

Sensory evaluation of fruits was carried out by standard method ISO 4121:1987 — liking of each sample fruit was characterised by parameters based on 12-point scale: colour, flavour, acidity, sweetness, firmness, and stone adherence. Using the scale 12 points means 'like extremely' and 1 point — 'dislike extremely'.

Data analysis was carried out using the General Linear Model functions in the IBM ${ }^{\circledR}$ SPSS $^{\circledR}$ Statistics programme 20.0 (SPSS Inc., Chicago, Illinois) and by Microsoft Office Excel 2007 packet (Redmond, Washington). The obtained data were analysed using descriptive statistics, analyses, tests and models: one-way analysis of variance (ANOVA) and significant differences determined by Least Significant Difference (LSD) criteria. Mean, standard deviation and minimal and maximal values were calculated for all parameters.

\section{RESULTS}

Dynamics of plum firmness. There were significant differences between cultivars in plum firmness at the time of harvesting (from 10.19 to $27.75 \mathrm{~N}$ ) (Fig. 1). Significant decrease of firmness occurred during four weeks of storage both in the control, and 1-MCP treated plum samples. Decrease of firmness at the end of the storage for control samples was: 'Minjona' - 52.6\%, 'Stanley' - 51.5\%, 'Victoria' $-48.56 \%$ and 'Sonora' — 39.2\%, and 'Adele' $17.8 \%$. For 1-MCP treated fruits firmness decreased as follows: 'Victoria' — 42.9\%, 'Minjona' — 33.9\%', 'Stanley' - 24.3\%, 'Adele' — 17.8\%. However, in 'Sonora' treated fruits firmness increased by $7.3 \%$. Significant $(p<$ 


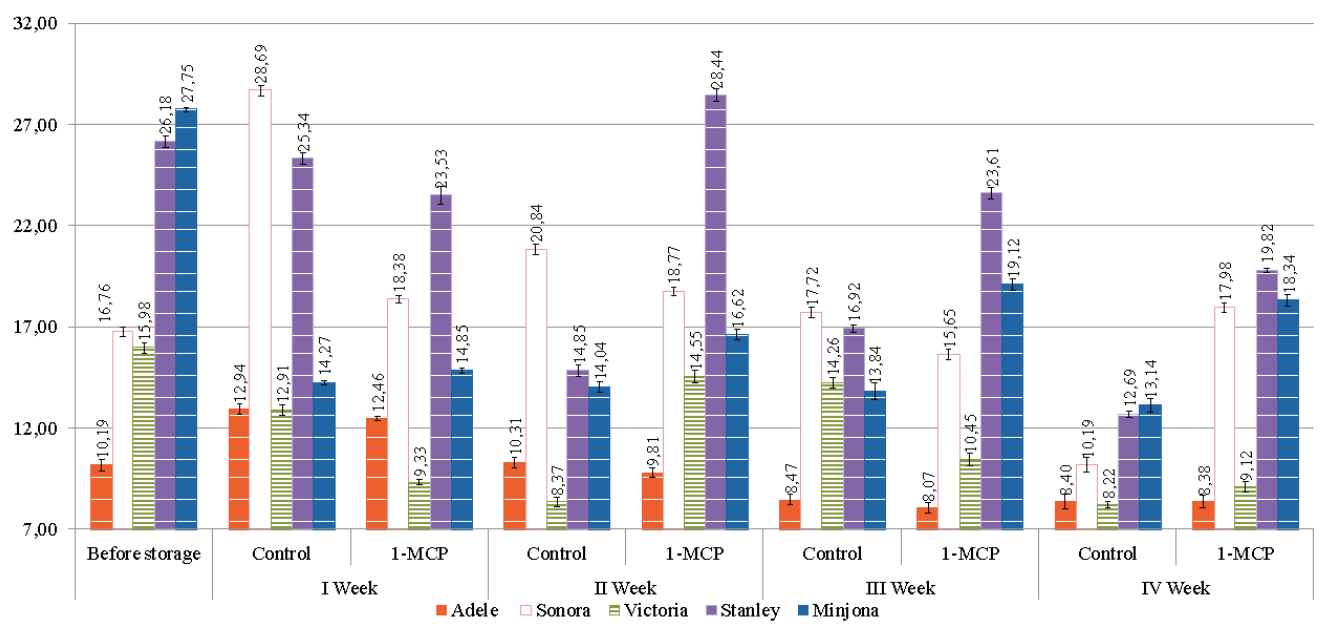

Fig. 1. Dynamics of plum firmness during storage. *Values represent the mean of twenty replications of ten fruits \pm standard deviation.
Table 1

DYNAMICS OF PLUM MASS LOSSES DURING STORAGE

\begin{tabular}{|c|c|c|c|c|}
\hline \multicolumn{5}{|c|}{ Mass losses, \% } \\
\hline & I week & II weeks & III weeks & IV weeks \\
\hline \multicolumn{5}{|c|}{ Adele } \\
\hline Control & $2.90^{\mathrm{a}}$ & $5.60^{\mathrm{a}}$ & $7.00^{\mathrm{a}}$ & $7.60^{\mathrm{a}}$ \\
\hline 1-MCP & $4.10^{\mathrm{b}}$ & $7.80^{\mathrm{b}}$ & $9.70^{\mathrm{b}}$ & $10.40^{\mathrm{b}}$ \\
\hline \multicolumn{5}{|c|}{ Sonora } \\
\hline Control & $4.30^{\mathrm{a}}$ & $8.30^{\mathrm{a}}$ & $15.30^{\mathrm{a}}$ & $19.60^{\mathrm{a}}$ \\
\hline 1-MCP & $3.50^{\mathrm{a}}$ & $9.10^{\mathrm{a}}$ & $11.30^{\mathrm{a}}$ & $12.90^{\mathrm{b}}$ \\
\hline \multicolumn{5}{|c|}{ Victoria } \\
\hline Control & $4.80^{\mathrm{a}}$ & $9.60^{\mathrm{a}}$ & $12.00^{\mathrm{a}}$ & $12.00^{\mathrm{a}}$ \\
\hline 1-MCP & $6.30^{\mathrm{a}}$ & $9.90^{\mathrm{a}}$ & $12.70^{\mathrm{a}}$ & $13.20^{\mathrm{a}}$ \\
\hline \multicolumn{5}{|c|}{ Stanley } \\
\hline Control & $1.30^{\mathrm{a}}$ & $2.20^{\mathrm{a}}$ & $2.80^{\mathrm{a}}$ & $3.10^{\mathrm{a}}$ \\
\hline 1-MCP & $1.50^{\mathrm{a}}$ & $2.10^{\mathrm{a}}$ & $2.90^{\mathrm{a}}$ & $3.50^{\mathrm{a}}$ \\
\hline \multicolumn{5}{|c|}{ Minjona } \\
\hline Control & $4.30^{\mathrm{a}}$ & $5.90^{\mathrm{a}}$ & $5.40^{\mathrm{a}}$ & $5.40^{\mathrm{a}}$ \\
\hline 1-MCP & $2.70^{\mathrm{a}}$ & $3.70^{\mathrm{a}}$ & $5.00^{\mathrm{a}}$ & $5.00^{\mathrm{a}}$ \\
\hline
\end{tabular}

*The different letters in the same column represent significant differences between values by the LSD. The mean difference is significant at the 0.05 level.

0.05) differences were observed between control and 1-MCP application for firmness after four weeks of fruit storage. A positive effect of 1-MCP on fruit firmness during storage weeks was observed for plum cultivars 'Sonora', 'Stanley', and 'Minjona'.

Dynamics of plum mass losses during storage. During storage, differences in fresh fruit mass losses between the control and 1-MCP treated plum samples occurred that were significant after four weeks of storage (Table 1). A significant $(p<0.05)$ positive effect of treatment by $1-\mathrm{MCP}$ on loss of plum fruit mass during four week of storage was observed only for cultivar 'Sonora'; no effect was observed in the four other cultivars. The percentage losses after four weeks of storage were about $9.5 \%$ in control samples (average for all cultivars) and $9.0 \%$ in 1-MCP treated samples (mean for all cultivars).
Dynamics of plum total acid content. Almost all plum cultivar fruits had higher concentration of total acids (Table 2) before storage (when degree of readiness was optimal). At the time of plum harvesting, concentration of total acids varied between 0.69 and $1.85 \%$. Plum cultivar 'Adele' fruits were as an exception - in fresh plums the total acid concentration was lower than after four weeks of storage. At the beginning of storage in control samples total acid concentration was $0.69 \%$, while after four weeks of storage $0.89 \%$ and in $1-\mathrm{MCP}$ treated fruits $-0.82 \%$. Total acid concentration increased by $28.9 \%$ in the control and $18.84 \%$ in 1-MCP treated samples (Table 2). During four weeks of storage significant decrease of total acid concentration occurred for all plum cultivars, while in cultivar 'Adele' fruits the total concentration of acids increased significantly $(p<$ $0.05)$ compared with the initial concentration of acids. In plum cultivars 'Sonora', 'Victoria', 'Stanley', and 'Minjona' control samples the concentration of total acid decreased by $36.25 \%, 21.62 \%, 10.74 \%$, and $28.43 \%$. After the treatment of plums by $1-\mathrm{MCP}$, total acid concentration significantly decreased in cultivars 'Sonora' by $32.50 \%$ and 'Minjona' by $8.80 \%$. Treatment by $1-\mathrm{MCP}$ did not have any effect on total acid concentration during storage of plum cultivar 'Stanley' fruits, but delayed acid formation in 'Adele' plums.

Dynamics of plum total soluble solid content. Higher total soluble solid concentration occurred before storage of plums. Among the five cultivar of plums, the highest total soluble solid concentration in control samples was in 'Sonora' - $15.60{ }^{\circ}$ Brix and 'Adele' -14.98 cultivar fruits (Table 3). After four weeks of storage, the concentration of total soluble solids in control plum cultivars significantly increased compared with the initial concentration and fluctuated between 11.69 and $15.82^{\circ}$ Brix. A similar increase of total soluble solid concentration was observed also in 1-MCP-treated samples. Total soluble solid concentration ranged from 11.42 to $15.80{ }^{\circ}$ Brix. After four weeks of storage, there was a significant $(p<0.05)$ difference in total soluble solid concentration between control and 1-MCPtreated fruits in 'Adele', 'Sonora', 'Victoria', and 'Minjona' cultivars; higher concentrations occurred in the control samples. 


\begin{tabular}{|c|c|c|c|c|c|c|}
\hline & & \multicolumn{5}{|c|}{ Total acids, $\%$} \\
\hline & & Before storage & I week & II week & III week & IV week \\
\hline \multicolumn{7}{|c|}{ Adele } \\
\hline Control & & $0.69 \pm 0.05$ & $1.05 \pm 0.09^{\mathrm{a}}$ & $1.02 \pm 0.04^{\mathrm{a}}$ & $0.99 \pm 0.05^{\mathrm{a}}$ & $0.89 \pm 0.05^{\mathrm{a}}$ \\
\hline \multirow[t]{2}{*}{ 1-MCP } & & $0.69 \pm 0.05$ & $0.79 \pm 0.08^{\mathrm{a}}$ & $0.89 \pm 0.05^{\mathrm{a}}$ & $0.92 \pm 0.05^{\mathrm{a}}$ & $0.82 \pm 0.05^{\mathrm{b}}$ \\
\hline & Sonora & & & & & \\
\hline Control & & $1.60 \pm 0.05$ & $1.31 \pm 0.05^{\mathrm{a}}$ & $1.54 \pm 0.05^{\mathrm{a}}$ & $1.15 \pm 0.05^{\mathrm{a}}$ & $1.02 \pm 0.05^{\mathrm{a}}$ \\
\hline \multirow[t]{2}{*}{ 1-MCP } & & $1.60 \pm 0.05$ & $1.18 \pm 0.05^{\mathrm{a}}$ & $1.28 \pm 0.05^{\mathrm{b}}$ & $1.18 \pm 0.05^{\mathrm{b}}$ & $1.08 \pm 0.05^{\mathrm{b}}$ \\
\hline & Victoria & & & & & \\
\hline Control & & $1.85 \pm 0.05$ & $1.64 \pm 0.05^{\mathrm{a}}$ & $1.18 \pm 0.05^{\mathrm{a}}$ & $1.58 \pm 0.05^{\mathrm{a}}$ & $1.45 \pm 0.05^{\mathrm{a}}$ \\
\hline \multirow[t]{2}{*}{ 1-MCP } & & $1.85 \pm 0.05$ & $1.58 \pm 0.05^{\mathrm{a}}$ & $1.48 \pm 0.05^{\mathrm{a}}$ & $1.64 \pm 0.05^{\mathrm{b}}$ & $1.48 \pm 0.05^{\mathrm{a}}$ \\
\hline & Stanley & & & & & \\
\hline Control & & $1.21 \pm 0.05$ & $1.08 \pm 0.05^{\mathrm{a}}$ & $0.96 \pm 0.05^{\mathrm{a}}$ & $0.99 \pm 0.05^{\mathrm{a}}$ & $1.08 \pm 0.05^{\mathrm{a}}$ \\
\hline \multirow[t]{2}{*}{ 1-MCP } & & $1.21 \pm 0.05$ & $1.15 \pm 0.05^{\mathrm{a}}$ & $0.86 \pm 0.05^{\mathrm{a}}$ & $0.99 \pm 0.05^{\mathrm{a}}$ & $1.05 \pm 0.05^{\mathrm{a}}$ \\
\hline & Minjona & & & & & \\
\hline Control & & $1.02 \pm 0.05$ & $1.02 \pm 0.05^{\mathrm{a}}$ & $0.73 \pm 0.05^{\mathrm{a}}$ & $0.73 \pm 0.05^{\mathrm{a}}$ & $0.73 \pm 0.05^{\mathrm{a}}$ \\
\hline 1-MCP & & $1.02 \pm 0.05$ & $1.08 \pm 0.05^{\mathrm{a}}$ & $0.99 \pm 0.05^{\mathrm{a}}$ & $0.93 \pm 0.05^{\mathrm{b}}$ & $0.93 \pm 0.05^{\mathrm{b}}$ \\
\hline
\end{tabular}

Table 3

DYNAMICS OF PLUM TOTAL SOLUBLE SOLID CONCENTRATION DURING STORAGE

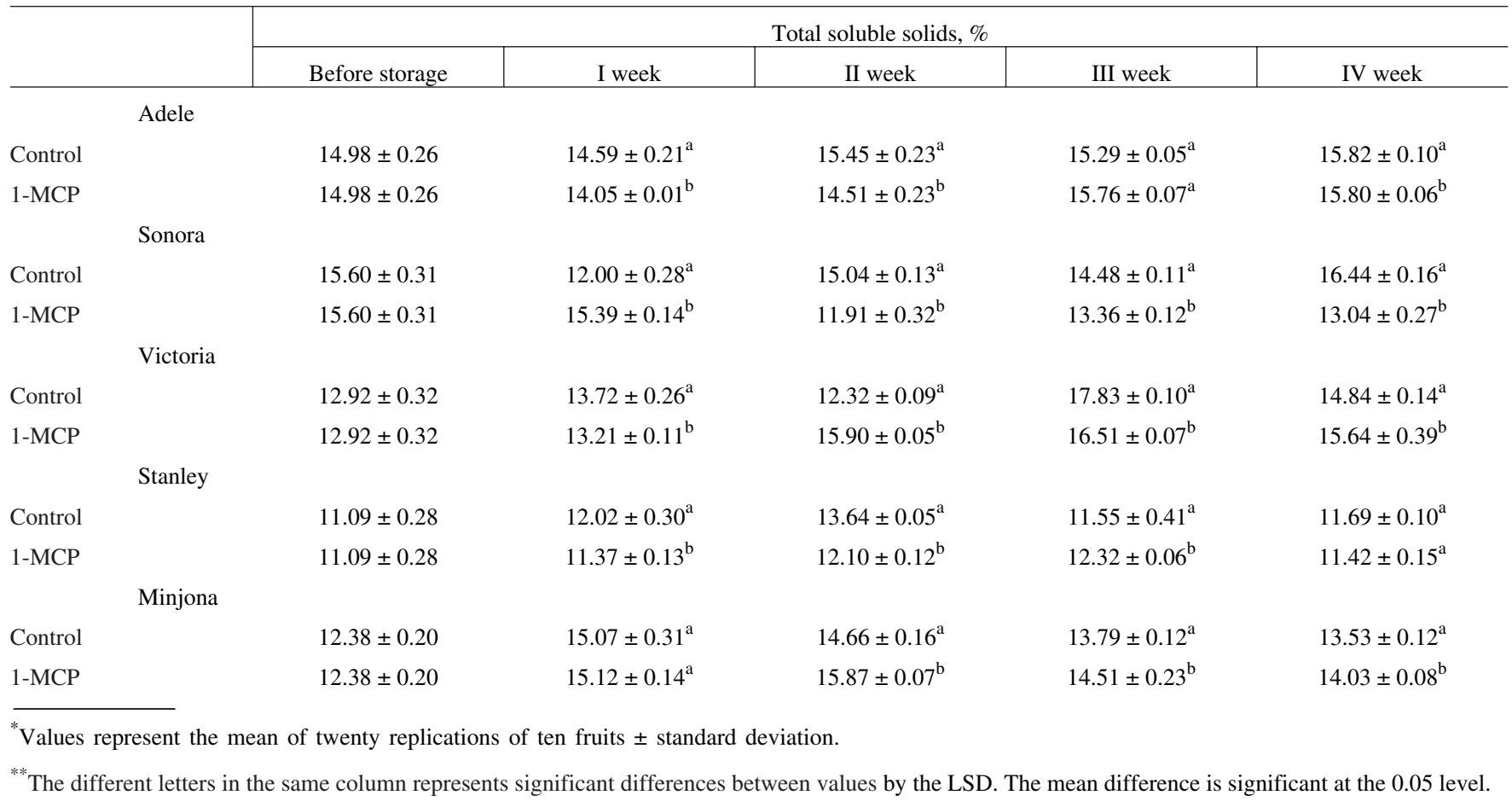

Sensory evaluation of plums. Sensory evaluation was conducted weekly to assess plum quality during storage (Figs. 2-7). Before storage, plums of cultivars 'Stanley' and 'Minjona' had distinctive colour intensity. 'Stanley' fruits also had distinctive firmness. Panellists observed the best stone adherence in fruits of cultivar 'Minjona' and 'Adele'. 'Sonora' was assessed as having distinctive acidity. After one week of storage, panellists recorded that sensory properties had considerably changed. Firmness, sweetness, and acidity in control samples of plum cultivar 'Adele' had de- 


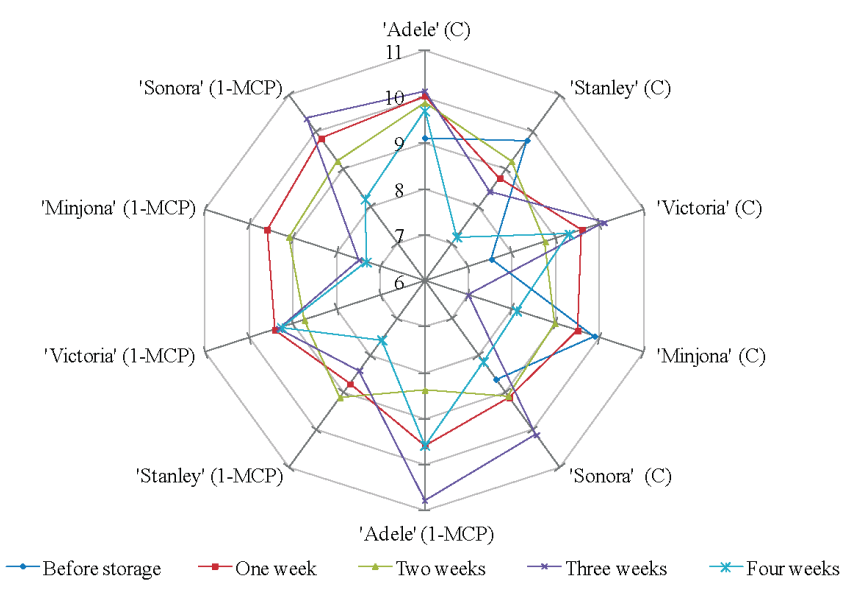

Fig. 2. Sensory evaluation of plum colour during storage. ${ }^{*}$ Points from 6 to 11 indicate the degree of liking obtained after sensory evaluation of particular attribute. ${ }^{* *} \mathrm{C}-$ control fruits, 1 -MCP-treated fruits with ethylene inhibitor 1-methylcyclopropene.

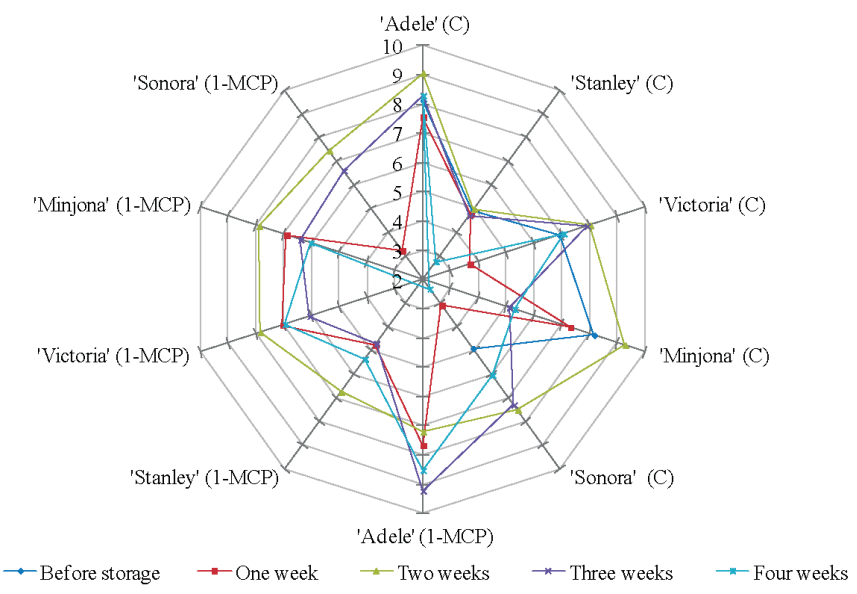

Fig. 3. Sensory evaluation of plum flavour during storage. * Points from 2 to 10 indicate the degree of liking obtained after sensory evaluation of particular attribute. ${ }^{* * *} \mathrm{C}$ - control fruits, 1-MCP-treated fruits with ethylene inhibitor 1-methylcyclopropene.

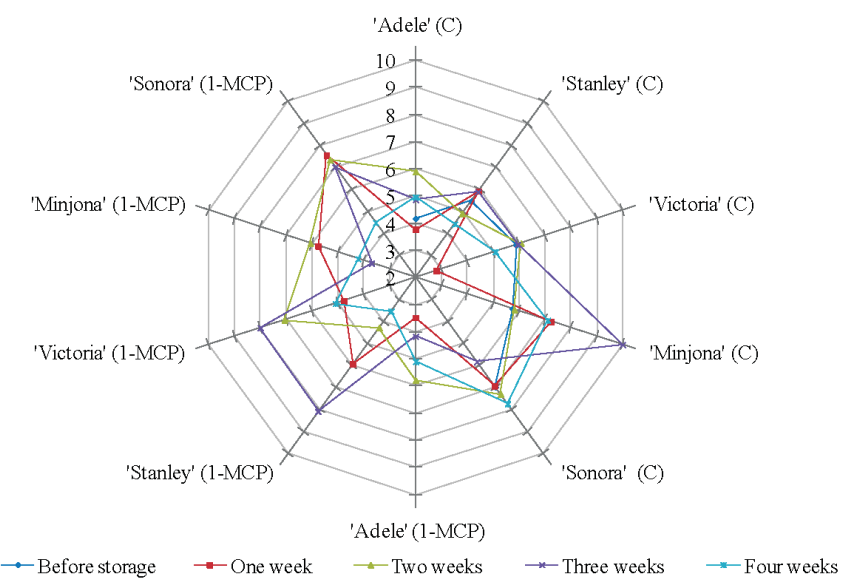

Fig. 4. Sensory evaluation of plum acidity during storage. Points from 2 to 10 indicate the degree of liking obtained after sensory evaluation of particular attribute. ${ }^{* *} \mathrm{C}-$ control fruits, 1-MCP-treated fruits with ethylene inhibitor 1-methylcyclopropene.

creased. Colour of cultivars 'Adele', 'Victoria', and 'Sonora' fruits had visibly increased. Scores for cultivar

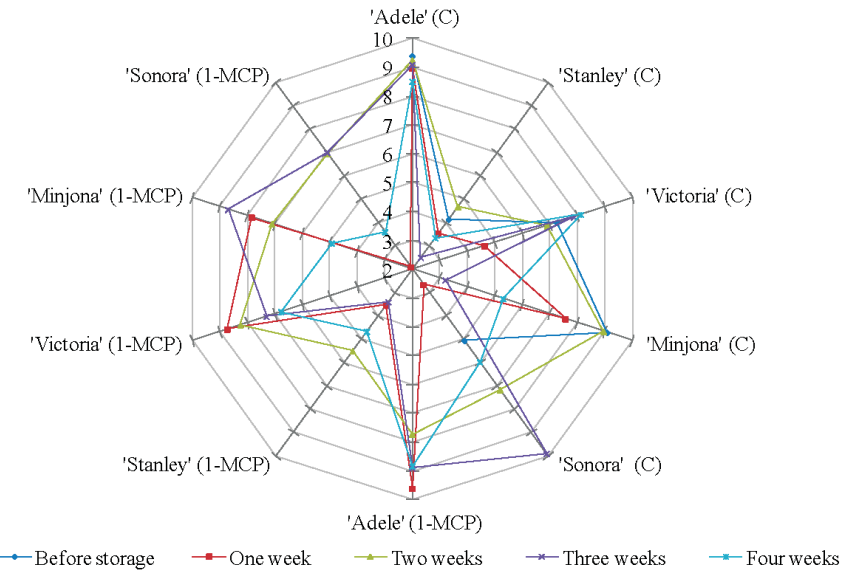

Fig. 5. Sensory evaluation of plum sweetness during storage. Points from 2 to 10 indicate the degree of liking obtained after sensory evaluation of particular attribute. ${ }^{* *} \mathrm{C}$ - control fruits, 1-MCP-treated fruits with ethylene inhibitor 1-methylcyclopropene.

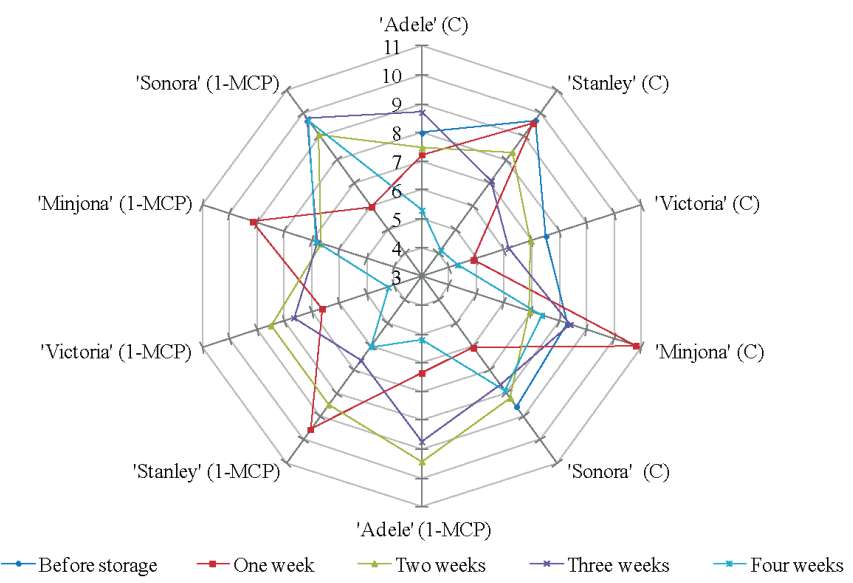

Fig. 6. Sensory evaluation of plum firmness during storage. Points from 3 to 11 indicate the degree of liking obtained after sensory evaluation of particular attribute. ${ }^{* *} \mathrm{C}$ - control fruits, 1-MCP - treated fruits with ethylene inhibitor 1-methylcyclopropene.

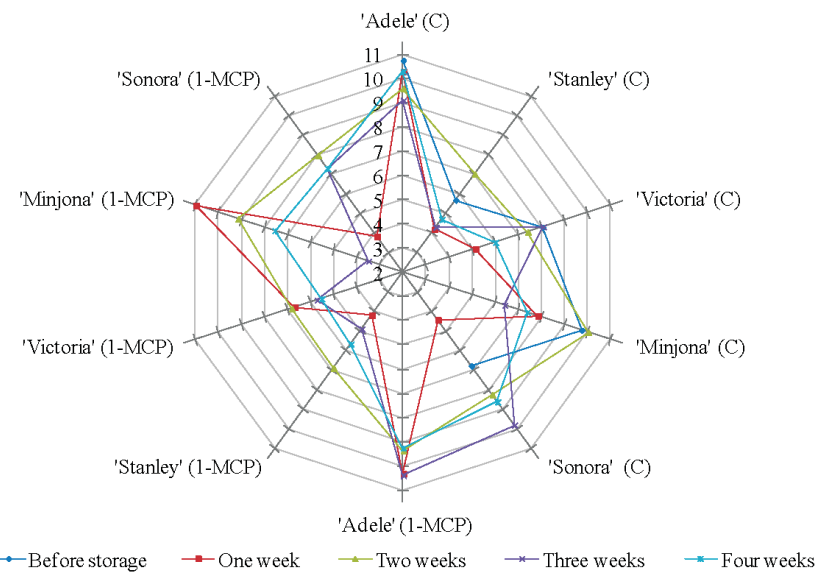

Fig. 7. Sensory evaluation of stone plum adherence during storage. Points from 2 to 11 indicate the degree of liking obtained after sensory evaluation of particular attribute. ${ }^{* *} \mathrm{C}$ - control fruits, $1-\mathrm{MCP}$ - treated fruits with ethylene inhibitor 1-methylcyclopropene.

'Adele' fruits treated by 1-MCP did not significantly differ from those of control samples. Plums of cultivar 'Adele' 
with and without 1-MCP treatment had higher sweetness and better stone adherence than in the other cultivars. After two weeks of plum storage, sensory properties had significantly changed. Panellists concluded that fruits of cultivar 'Stanley' and 'Sonora' had distinctive firmness, while cultivar 'Stanley' had the poorest stone adherence. In plums treated with 1-MCP, cultivar 'Minjona' plums had better stone adherence than cultivar 'Stanley' fruits. Panellists noted that control samples of cultivar 'Adele' and 'Minjona' plums had distinctive flavour and sweetness, while fruits of cultivar 'Victoria' (1-MCP treated) and 'Sonora' (control and 1-MCP treated) had increased acidity. After three weeks of storage, plums of cultivar 'Adele' (control and 1-MCP-treated) had better flavour than other cultivars, with extensive colour intensity, sweetness, and better stone adherence. Fruits of cultivar 'Victoria' (control and by 1-MCP-treated) had distinctive colour intensity. Samples treated with 1-MCP were more acidic and control samples had more intense flavour. As in the previous periods, after four weeks of storage panellists highlighted that plums of cultivar 'Adele' (control and 1-MCP-treated) had distinctive colour, flavour, sweetness, and fruits are firmer with good stone adherence. Plums of cultivar 'Victoria' (control and 1-MCP-treated) had distinctive colour, flavour, and control samples were sweeter. The total acid concentration after four weeks of storage in cultivar 'Sonora' fruits was $1.02 \%$, while in cultivar 'Victoria' plums $-1.45 \%$, and 'Stanley' - $1.08 \%$. However, panellists considered that fruits of cultivar 'Sonora' (control) were sourer than the others.

\section{DISCUSSION}

Fruit firmness and colour are much appreciated sensorial attributes for consumers, and usually these factors determine fruit acceptability on the market (Valero et al., 2003). Changes of fruit firmness are a physiological process that occurs during fruit ripening on the tree, during cold storage and retail handling (Delwiche, 1987; Chen, 1996; Abbott, 1999). Based on our results it was evident that firmness was considerably decreased during plum storage and softening was more pronounced during four weeks of storage (Table 1). Considerable softening was observed in plum control samples without 1-MCP treatment. Extensive softening of the fruit can be attributed to enzyme-mediated solubilisation of pectin substances as a result of ripening (Hussain et al., 2015). We found that 1-MCP application is very effective for the prevention of plum softening processes. Results from the current study indicate that firmness was comparatively higher in plums treated with 1-MCP than in control fruits. Our findings are also coincide with previous studies that noted greater reduction of firmness during 30 days of control fruits than those treated with 1-MCP (Salvador et al., 2003).

Moisture loss is one of the major factors that limit the marketable life of fresh products (Lee et al., 1995). Moisture induces water stress, which accelerates ageing of fruits (Kader, 1986). Due to moisture, undesirable alterations in appearance such as softening of tissue and mass loss takes place. Most fruits and vegetables become unmarketable when they lose 5-10\% of their fresh mass (Burton, 1982). One of the main reasons of mass loss during storage is water transpiration. Transpiration is a process of mass transfer in which the water vapour permeate from the fruit surface of the product to the surrounding atmosphere (Burr et al., 1973). The second reason for mass loss is metabolic processes, which take place during storage and are associated mainly with respiratory metabolism. It has been observed that treatment with $1-\mathrm{MCP}$ can significantly reduce the mass loss of plums during storage (Palau et al., 2003; Crisosto et al., 2009). Our study showed (Table 1) that treatment with 1-MCP did not have any effect on reducing the mass losses of plum cultivar 'Adele' 'Victoria', 'Stanley', and 'Minjona' fruits, while a positive effect was observed for 'Sonora', plums. This can be explained by different processes in ripening, which are accompanied by changes in colour, texture and aroma enrichment. Fruit ripening is not regulated exclusively by ethylene (Nishiyama et al., 2007). Apparently, both ethylene-dependent and independent pathways coexist to coordinate the climacteric fruit ripening process (Alexander and Grierson, 2002). Another explanation might be that moisture continuously evaporates during plum storage due to equality of water vapour pressure in the storage atmosphere and on the produce surface. Product characteristics such as the surface structure of the cuticular layer and the specific surface area of fruits in contact with the air directly affect the rate of evaporation (Patel et al., 1988). Therefore, difference of mass losses between cultivar plums can be explained by different size and by different thickness of cuticular layer (data not shown).

Malic, citric, and tartaric acids are the main organic acids in plums. Concentration of organic acid depends on cultivar and degree of plum maturity. During ripening of plums, decrease of malic acid concentration occurs predominantly, leading to decrease in acidity (Hoehn et al., 2005). We observed decrease of organic acid concentration during fruit storage for four weeks. Total acid concentration for plums of cultivar 'Victoria' $(1.85 \pm 0.05 \%)$ and 'Sonora' (1.60 \pm $0.05 \%$ ) was highest among cultivars. The concentration of total acids in plums during four weeks of storage decreased on average by $13.61 \%$ in the control and by $11.14 \%$ in plums treated with 1-MCP. During storage, ripening involved conversion of malic acid by enzyme malate dehydrogenase (EC 1.1.1.37) into oxaloacetic acid. Several researchers have suggested that 1-MCP treatment can considerably delay the decrease of total acid content in plums during cold storage (Fan et al., 1999; Fan and Mattheis, 1999a; 2001; Watkins et al., 2000, Pre-Aymard et al., 2003, Pre-Aymard et al., 2005, Saftner et al., 2003, Zanella, 2003). Our results indicate that treatment with 1-MCP had a positive effect on plum cultivars 'Sonora' and 'Minjona', while no effect was observed for cultivar 'Stanley' fruits.

Total soluble solid concentration is an indicator of plum internal quality, which affects consumers' acceptance (Paz et al., 2008). Based on consumer acceptance, Vangdal (1980) estimated that plums with less than $12.5 \%$ soluble solid 
concentration were not accepted from most of the consumers (Vangdal, 1980). We found that during storage the concentration of soluble solids in control plums increased (Table 3). Increase of soluble solid concentration serves as an indicator of fruit ripening, which was observed during four weeks of plum storage.

Increasing of total soluble solid concentration occurs due to conversion of higher polysaccharides into the simple sugars such as glucose, which are more soluble in solutions.

Fruits of plum cultivars 'Adele', 'Sonora', 'Victoria', and 'Minjona' without 1-MCP treatment continuously ripened during storage time. After four weeks of plum storage, total soluble solids concentration increased by $5.60 \%$ in 'Adele'), $5.37 \%$ in 'Sonora', $14.86 \%$ in 'Victoria' and by $9.28 \%$ in 'Minjona'. Total soluble solid concentration in the control plum cultivar 'Stanley' did not significantly change during the four weeks of storage. In this case, perhaps ripening process in this plum cultivar does not occur during storage. In plum samples treated with 1-MCP, after four weeks of storage total soluble solid concentration in plum cultivars 'Adele' and 'Sonora' was significantly lower than in control samples. The decrease of soluble substances can be explained by oxidative breakdown of sugars in respiration, which initiates the catabolic processes that trigger the cleavage reaction of sugars (Hussain et al., 2010). Utilization of sugars as substratum for fungal growth indicates that catabolic processes were initiated that triggered the cleavage reaction of sugars. In plum cultivar 'Stanley' no statistically significant differences in total soluble solid concentration were observed. In the present study, no positive effect of 1 -MCP treatment on plum total soluble concentration was observed. In previous studies treatment with 1-MCP had no effect on the total soluble solid concentration either (Menniti et al., 2004).

One of the most important negative aspects of 1-MCP is reduction in volatile compound synthesis by eliminating sensitivity to ethylene. These compounds are responsible for the fruit flavour (Mitcham et al., 2001). Sensory obtained results in this study did not substantiate the idea that 1-MCP significantly suppresses the synthesis of volatile compounds. The panellists highlighted that fruits subjected to treatment by 1-MCP did not differ in flavour in comparison with control fruit samples. However, 1-MCP treated fruits had more pronounced sourness and firmness. On the other hand, there were no negative effects of 1-MCP on the colour intensity of stored plums.

The results of our experiment demonstrated that application of 1-MCP treatment is an effective tool with great positive effect for most climacteric stone fruits. The study showed that 1-MCP application positively affected the quality of plum fruits. During four weeks of plum storage, firmness in plums treated by $1-\mathrm{MCP}$ was relatively higher in fruits than before the storage. In particular, 1-MCP application maintained the quality parameters of 'Sonora', 'Minjona', and 'Sonora' plum cultivars. A significantly higher positive effect of 1-MCP on mass loss was observed only in one of five plum cultivars — 'Sonora'.

\section{ACKNOWLEDGMENTS}

This study was supported by ESF Project No. 2013/0048/ 1DP/1.1.1.2.0/13/APIA/VIAA/008 "Creation of a new research group for propagation of stone fruits, quality improvement of generative processes and possibilities of fruit use”.

\section{REFERENCES}

Abbott, J. A. (1999). Quality measurement of fruits and vegetables. Postharv. Biol. Technol., 15 (3), 207-225.

Abdi, N., McGlasson, W. B., Holford, P., Williams, M., Mizrahi, Y. (1998). Responses of climacteric and suppressed-climacteric plums to treatment with propylene and 1-methylcyclopropene. Postharvest Biol. Tech., 14 (1), 29-39.

Alexander, L. Grierson, D. (2002). Ethylene biosynthesis and action in tomato: A model for climacteric fruit ripening. J. Exp. Bot., 53 (377), 2039-2055.

Bapat, V. A., Trivedi, P. K., Ghosh, A., Sane, V. A., Ganapathi, T. R., Nath, P. (2010). Ripening of fleshy fruit: Molecular insight and the role of ethylene. Biotechnol. Adv., 28 (1), 94-107.

Blankenship, S. M., Dole, J. M. (2003). 1-Methylcyclopropene: A review. Postharvest Biol. Technol., 28 (1), 1-25.

Burg, S. P., Burg, E. A. (1967). Molecular requirements for biological activity of ethylene. Plant Physiol., 42 (1), 144-152.

Burr, H. K., Reeve, R. M. (1973). Potatoes. In: Food Dehydration. Van Arsdel, W. B., Copley, M. J., Morgan, A. I. (Eds.). AVI Westport, Connecticut, pp. 83-157.

Burton, W. G. (1982). Postharvest Physiology of Food Produce. Longman, London, UK. 339 pp.

Candan, A. P., Graell, J., Crisosto, C., Larrigaudiere, C. (2006). Improvement of storability and shelf-life of 'Blackamber' plums treated with 1-methylcyclopropene. Food Sci. Technol. Int., 12 (5), 437-443.

Chen, P. (1996). Quality evaluation technology for agricultural products. Proceedings of the International Conference on Agricultural Machinery Engineering, Seoul, Korea, November 12-15, Vol. 1. Korean Society for Agricultural Machinery, Seoul, pp. 171-204.

Crisosto, C. H., Lurie, S., Retamales, J. (2009). Stone fruits. In: Modified and Controlled Atmospheres for the Storage, Transportation, and Packaging of Horticultural Commodities. Yahia. E. M. (Ed.). CRC Press/Taylor \& Francis Group, Boca Raton, FL, pp. 287-315.

Delwiche, M. J. (1987). Theory of fruit firmness sorting by impact forces. Trans. Amer. Soc. Agr. Eng., 30 (4), 1160-1171.

Fan, X., Mattheis, J. P. (1999). Methyl jasmonate promotes degreening of apple fruit independent of ethylene action. HortScience, 34 (2), 310-312.

Fan, X. T., Blankenship, S. M., Mattheis, J. P. (1999). 1-methylcyclopropene inhibits apple ripening. J. Amer. Soc. Hort. Sci., 124 (6), 690-695.

Fan, X. T., Mattheis, J. P. (1999a). Development of apple superficial scald, soft scald, core flush, and greasiness is reduced by MCP. J. Agric. Food. Chem., 47 (8), 3063-3068.

Fan, X. T., Mattheis, J. P. (2001). 1-Methylcyclopropene and storage temperature influence responses of 'Gala' apple fruit to gamma irradiation. Postharvest Biol. Tec., 23 (2), 143-151.

Galmarini, M. V., Symoneaux, R., Chollet, S., Zamora, M. C. (2013). Understanding apple consumers expectations in terms of likes and dislikes: Use of comment analysis in a cross-cultural study. Appetite, 62, 27-36.

Hoehn, E., Gasser, B., Naepflin, B., Lander, J. (2005). Consumer expectations and soluble solids, acidity and firmness of plums (Prunus domestica 'Cacaks Beauty') Acta. Hort., 3, 682.

Hussain, P. R., Meena, R. S., Dar, M. A., Wani, A. M. (2010). Carboxymethyl cellulose coating and low-dose gamma irradiation improves storage quality and shelf life of pear (Pyrus communis L. Cv. Barlett/William). J. Food Sci., 75, 586-596. 
Hussain, P. R., Suradkar, P. P., Wani, A. M., Dar, M. A. (2015). Retention of storage quality and post-refrigeration shelf-life extension of plum (Prunus domestica L.) cv. Santa Rosa using combination of carboxymethyl cellulose (CMC) coating and gamma irradiation. Radiat. Phys. Chem., 107, 136-148.

Ievins, G. (2012). 1-Aminocyclopropane-1-carboxylic acid-independent ethylene production by disintegrated plan cells. Env. Exper. Biol., 10, 99-105.

Juhnevica, K., Skudra, L., Skrivele, M., Radenkovs, V., Seglina, D., Stepanovs, A. (2013). Effect of 1-methylcyclopropene treatment on sensory characteristics of apple fruit. Env. Exper. Biol., 11, 99-105.

Kader, A. A. (1986). Biochemical and physiological basis for effects of controlled atmosphere and modified atmosphere on fruits and vegetables. $F d$. Technol., 40 (5), 99.

Kader, A. A. (1987) Respiration and gas exchanges of vegetables. In: Postharvest Physiology of Vegetables. Weichman, J. (Ed). Marcel Rekker, New York, NY, p. 25-30

Khan, A. S., Singh, Z. (2009). 1-MCP application suppresses ethylene biosynthesis and retards fruit softening during cold storage of 'Tegan Blue' Japanese plum. Plant Sci., 176 (4), 539-544.

Lee, L., Arul, J., Lencki, R., Castaigne F. (1995). A review on modified atmosphere packaging and preservation of fresh fruits and vegetables: Physiological basis and practical aspects. Part I. Packag. Technol. Sci., 8 (6), $315-331$.

Martinez-Romero, D., Dupille, E., Guillen, F., Valverde, J. M., Serrano, M., Valero, D. (2003). 1-Methylcyclopropene increases storability and shelf life in climacteric and nonclimacteric plums. J. Agric. Food. Chem., 51 (16), 4680-4686.

Mathooko, F. M., Tsunashima, Y., Owino, W. Z. O., Kubo, Y., Inaba A. (2001). Regulation of genes encoding ethylene biosynthetic enzymes in peach (Prunus persica L.) fruit by carbon dioxide and 1-methylcyclopropene. Postharvest Biol. Technol., 21 (3), 265-281.

McKeon, T. A., Fernandez-Maculet, J. C., Yang, S. F. (1995). Biosynthesis and metabolism of ethylene. In: Plant Hormones: Physiology, Biochemistry, Molecular Biology. Davies, P. J. (Ed). Kluwer Academic Publishers, Dordrecht, pp. 118-139.

Menniti, A. M., Gregori, R., Donati, I. (2004). 1-Methylcyclopropene retards postharvest softening of plums. Postharvest Biol. Tec., 31 (3), 269-275.

Mitcham, B., Mattheis, J., Bower, J., Biasi, B., Clayton, M. (2001). Responses of European Pears to 1-MCP. Perishables Handling Quarterly, 108, 16-19.

Nishiyama, K., Guis, M., Rose, J. K., Kubo, Y., Bennett, K. A., Wangjin, L., Kato, K., Ushijima, K., Nakano, R., Inaba, A., Bouzayen, M., Latché, A., Pech, J. C., Bennett, A. B. (2007). Ethylene regulation of fruit softening and cell wall disassembly in Charentais melon. J. Exp. Bot., 58 (6), $1281-1290$

Received 25 November 2016
Palou, L., Crisosto, C. H., Garner, D., Basinal, L. M. (2003). Effect of continuous exposure to exogenous ethylene during cold storage on postharvest decay development and quality attributes of stone fruits and table grapes. Postharvest Biol. Tec., 27 (3), 243-254

Patel, P. N., Pai, T. K., Sastry, S. K. (1988). Effects of temperature, relative humidity and storage time on the transpiration coefficients of selected perishables. ASHRAE Trans., 94, 1563-1587.

Paz, P., Sánchez, M. T., Pérez-Marín, D., Guerrero, J. E., Garrido-Varo, A. (2008). Nondestructive determination of total soluble solid content and firmness in plums using near-infrared reflectance spectroscopy. J. Agric. Food Chem., 56 (8), 2565-2570.

Pre-Aymard, C., Fallik, E., Weksler, A., Lurie, S. (2005). Sensory analysis and instrumental measurements of 'Anna' apples treated with 1-methylcyclopropene. Postharvest Biol. Tec., 36 (2), 135-142.

Pre-Aymard, C., Weksler, A., Lurie, S. (2003). Responses of 'Anna' a rapidly ripening summer apple to 1-methylcyclopropene. Postharvest Biol. Tec., 27 (2), 163-170.

Saftner, R. A., Abbott, J. A., Conway, W. S., Barden, C. L. (2003). Effects of 1-methylcyclopropene and heat treatments on ripening and postharvest decay in 'Golden Delicious' apples. J. Amer. Soc. Hortic. Sci., 128 (1), $120-127$.

Salvador, A., Cuquerella, J., Martinez-Jevega J. M. (2003). 1-MCP treatment prolongs postharvest life of 'Santa Rosa' plums. J. Food Sci., 68 (4), 1504-1510.

Sisler, E. C., Lallu, N. (1994). Effect of diazo-cyclopentadiene (DACP) on tomato fruits harvested at different ripening stages. Postharv. Biol. Technol., 4 (3), 245-254.

Valero, D., Martinez-Romeroa, D., Valverdea, J. M., Guilléna, F., Serranob, M. (2003). Quality improvement and extension of shelf life by 1-methylcyclopropene in plum as affected by ripening stage at harvest. Innov. Food Sci. Emerg., 4 (3), 339-348.

Vangdal, E. (1980). Threshold values of soluble solids in fruit determined for the fresh fruit market. Acta Agr. Scand., 30 (4), 445-448.

Watkins, C. B. (2002). Ethylene synthesis, mode of action, consequences and control. In: Fruit Quality and Its Biological Basis. Knee, M. (Ed.). Sheffield Academic Press, Sheffield, pp. 180-224.

Watkins, C. B. (2006). The use of 1-methylcyclopropene (1-MCP) on fruits and vegetables. Biotechnol. Adv., 24 (4), 389-409.

Watkins, C. B., Nock, J. F., Whitaker, B. D. (2000). Responses of early, mid and late season apple cultivars to postharvest application of 1-methylcyclopropene (1-MCP) under air and controlled atmosphere storage conditions. Postharvest Biol. Tec., 19 (1), 17-32

Zanella, A. (2003). Control of apple superficial scald and ripening — a comparison between 1-methylcyclopropene and diphenylamine postharvest treatments, initial low oxygen stress and ultra low oxygen storage. Postharvest Biol. Tec., 27 (1), 69-78.

\section{SĀKOTNĒJIE REZULTĀTI PAR 1-METILCIKLOPROPĒNA IETEKMI UZ LATVIJĀ AUDZĒTO PLŪMJU KVALITĀTI}

Plūmes ir vieni no biežāk patērējamiem aug̣̣iem Latvijā. Plūmes ir tipiski klimaktēriskie augḷi, kas nogatavināšanas laikā nepārtraukti elpo. Elpošanas intensitāte saistîta ar autokatalîtiskā etilēna veidošanos un ir atkarīga no plūmju škirnes. Plūmju uzglabāšanas laikā turpinās metaboliskie procesi, kas izraisa aug̣̣u kvalitātes pasliktināšanos. Tādēẹ šī pētījuma mērḳis bija pārbaudīt 1-metilciklopropēna (1-MCP) inhibējošo efektu uz etilēna darbību un to ietekmi uz piecu plūmju škirṇu ('Minjona', 'Sonora', 'Stanley, 'Viktorija', 'Adele') fizikāli kīmiskiem un sensoriem rādītājiem. Lai novērtētu aug̣̣u kvalitatīvās izmaiṇas visā uzglabāšanas laikā veiktas sekojošas analīzes: masas zudumi, kopējo skābju un šķistošās sausnas saturs, cietība un sensorās īpašības (izskats, smarža un garša, skābums, cietība, kauliņa atdalīšanās). Iegūtie rezultāti rāda, ka, izmantojot 1-MCP, plūmju cietība četru uzglabāšanas nedēlu laikā samazinājās minimāli, bet kopējo skābju un šḳistošās sausnas saturs bija būtiski atškirīgs apstrādātiem un neapstrādātiem augliem. Sensorās analīzes rezultāti norāda, ka nav būtiskas atškirības starp plūmju smaržu un krāsu ar 1-MCP apstrādātiem un neapstrādātiem augliem. Secināts, ka ar 1-MCP apstrādāto plūmju škirṇu aug̣̣i ir cietāki un skābāki. 